\section{Effects of Organic Fertilization and Cover Crops on an Organic Pepper System}

\author{
K. Delate ${ }^{1,3}$, C. Cambardella ${ }^{2}$, and A. McKern ${ }^{1}$
}

AdDITIONAL INDEX WORDs. certified organic, hairy vetch, Vicia villosa, rye, Secale cereale, strip-tillage, Rbizoctonia solani, gypsum

SUMMARY. With the continuing $20 \%$ growth rate in the organic industry, organic vegetable crop production has increased to 98,525 acres in the United States. The requirement for certified organic vegetable producers to implement a soil-building plan has led to the development of soil fertility systems based on combinations of organic fertilizers and cover crops. To determine optimal soil fertility combinations, conventional and organic bell pepper (Capsicum annuum) production was evaluated from 2001 to 2003 in Iowa, comparing combinations of two synthetic fertilizers and three compost-based organic fertilizers, and a cover crop treatment of hairy vetch (Vicia pillosa) and rye (Secale cereale) in a strip-tilled or fully incorporated cover crop system. Organic pepper growth and yields equaled or surpassed conventional production when nitrogen $(N)$ was provided at 56 or 112 $\mathrm{kg} \cdot \mathrm{ha}^{-1}$ from compost-based organic fertilizer. Soil analysis revealed higher $\mathrm{N}$ in plots where cover crops were tilled compared with strip-tilled plots, leading to recommendations for sidedressing $\mathbf{N}$ in strip-tilled organic pepper production. Increased incidence of disease was also detected in strip-tilled plots. Postharvest weight loss after 6 weeks in storage was similar in organic and conventional peppers. The addition of calcium and sulfur products in conventional or organic fertilizer regimes did not increase pepper production or postharvest storage potential. Despite application challenges, cover crops will remain as critical components of the organic farm plan for their soil-building benefits, but supplementation with approved $\mathrm{N}$ sources may be required for optimal pepper production. Organic growers should conduct their own tests of organic-compliant soil amendments to determine cost effectiveness and value for their site before large-scale application.

$\mathrm{O}$ rganic production increased to $4,054,429$ acres in the United States in 2005 (U.S. Department of Agriculture, 2007a), with 98,525 acres in organic vegetable crops. This increase has been attributed to the implementation of consistent federal standards for products marketed as "organic" in Oct. 2002 (U.S. Department of Agriculture, 2007b) and a growing consumer preference for lower pesticide residues in food (Baker et al., 2002). In addition, negative environmental impacts associated with intensive mineral fertilization in conventional

Support for this project came from the Leopold Center for Sustainable Agriculture, the Muscatine Growers' Association, Midwest Bio-Ag, and Johnny's Selected Seeds.

We gratefully acknowledge the help of the following persons who assisted with this research: V. Lawson, H. Friedrich, N. Wantate, J. Alvaro, K. Schroeder, J. Petersen, V. Forte, P. Sambo, S. Sans Tercel, J. Roscoe, K. Ramos, M. Stoskoph, and C. Torres Sanchez.

${ }^{1}$ Department of Horticulture, Iowa State University, Ames, IA 50011-1100

${ }^{2}$ U.S. Department of Agriculture, Agriculture Research Service, National Soil Tilth Laboratory, Ames, IA 50011-3120

${ }^{3}$ Corresponding author. E-mail: kdelate@iastate.edu. production (Pimentel et al., 1989; Venterea and Rolston, 2000) have encouraged many producers to investigate organic methods. To enter the expanding organic market and meet certified organic requirements, producers must implement a soil-building plan in accordance with the USDA National Organic Program (NOP) of the Agriculture Marketing Service (U.S. Department of Agriculture, 2007b). Some of the most critical needs of organic vegetable growers, identified through national surveys (Walz, 2004) and statewide focus groups (Delate and DeWitt, 2004), have included soil fertility and pest management strategies. Fertility sources for organic vegetable crops generally include crop rotations and combinations of composted manure or cover crops (Gaskell et al., 2000). Methods for ending cover crops before planting vegetable crops include herbicides, mowing, rolling, roll-chopping, undercutting, and roto-tilling (Carrera et al., 2004), but because synthetic herbicides are disallowed in organic production, termination of cover crops through organic-compliant methods constitutes a major challenge. Although the majority of cover crop studies have been reported from conventional systems using herbicide inputs, cover crop combinations developed in conventional systems can help inform organic systems. Effective cover crops for organic systems have included combinations of barley (Hordeum vulgare), rye, wheat (Triticum vulgare), hairy vetch, and crimson clover (Trifolium incarnatum) because of their quick establishment, ability to overwinter, competitiveness with weeds, and ease of being killed with mechanical methods (Creamer and Bennett, 1997; Nelson et al., 1991). Leguminous cover crops provide the greatest potential for improving yields, but cereal crops generally result in higher levels of soil organic matter than legumes, help to suppress weeds, and immobilize soil $\mathrm{N}$, which can reduce nitrate leaching during winter months (Snapp et al., 2005). Fall-planted cover crops can eliminate spring tillage, improve soil quality, and decrease the need for pesticides for certain pests (Masiunas et al., 1995).

\begin{tabular}{lllc}
\hline $\begin{array}{l}\text { Units } \\
\text { To convert U.S. to SI, } \\
\text { multiply by }\end{array}$ & U.S. unit & SI unit & $\begin{array}{l}\text { To convert SI to U.S., } \\
\text { multiply by }\end{array}$ \\
\hline 0.4047 & acre $(\mathrm{s})$ & $\mathrm{ha}$ & 2.4711 \\
29.5735 & $\mathrm{fl} \mathrm{oz}$ & $\mathrm{mL}$ & 0.0338 \\
0.3048 & $\mathrm{ft}$ & $\mathrm{m}$ & 3.2808 \\
0.0929 & $\mathrm{ft}^{2}$ & $\mathrm{~m}^{2}$ & 10.7639 \\
2.54 & inch(es) & $\mathrm{cm}$ & 0.3937 \\
25.4 & inch(es) & $\mathrm{mm}$ & 0.0394 \\
1.1209 & lb/acre & $\mathrm{kg} \cdot \mathrm{ha}^{-1}$ & 0.8922 \\
1 & micron & $\mu \mathrm{m}$ & 1 \\
1000 & mmho/cm & $\mu S \cdot \mathrm{cm}^{-1}$ & 0.0010 \\
28.3495 & $\mathrm{oz}$ & $\mathrm{g}$ & 0.0353 \\
0.001 & $\mathrm{ppm}$ & $\mathrm{mg} \cdot \mathrm{g}^{-1}$ & 1000 \\
1 & $\mathrm{ppm}$ & $\mu \mathrm{g} \cdot \mathrm{g}^{-1}$ & 1 \\
$\left({ }^{\circ} \mathrm{F}-32\right) \div 1.8$ & ${ }^{\circ} \mathrm{F}$ & ${ }^{\circ} \mathrm{C}$ & $\left(1.8 \times{ }^{\circ} \mathrm{C}\right)+32$
\end{tabular}


Although the majority of organic producers incorporate cover crops before planting, more recently, conservation tillage systems have been promoted to obtain the benefits of conventional no-till or strip-tilled systems, including reducing soil erosion, conserving soil moisture, and increasing soil fertility through cover crop residues (Hoyt et al., 1994). Success of conservation tillage systems is dependent on sufficient groundcover provided by the cover crops, minimum cover crop mulch disturbance from seeding or transplanting, and effective weed management outside of the growing season (Morse, 1999). Yield reductions have resulted from poor seed coverage, reduced soil temperatures, and $\mathrm{N}$ immobilization during cover crop decomposition. No-till vegetable systems have produced mixed results across the United States. Abdul-Baki and Teasdale (1997a) reported a 35\% increase in snap bean (Phaseolus vulgaris) yield in no-till hairy vetch plots compared with bare soil plots provided equivalent fertilization. Griffin et al. (2000) found that no additional $\mathrm{N}$ was required to compete with conventional sweet corn (Zea mays) yields in a no-till system with alfalfa $(\mathrm{Medi}$ cago sativa) and rye/hairy vetch cover crops. Hoyt (1999) reported no difference in squash (Cucurbita maxima) yields in plowed, strip-tilled, or no-tilled systems, while Herrero et al. (2001) demonstrated equivalent yields in fallow and no-till tomato (Solanum lycopersicum) systems. In the absence of herbicides, Carrera et al. (2004) found that cover crops increased no-till sweet corn yield by reducing weed biomass and improving crop competitiveness. Despite a $23 \%$ reduction in sweet corn plant population in hairy vetch/rye plots compared with bare soil, sweet corn yields were increased by $30 \%$ over bare soil plots, and by $43 \%$ with hairy vetch.

Compared with no-till systems, strip-tillage prepares a seed bed of loosely cultivated soil in a surface mulch (Hoyt et al., 1994), combines the benefits of no-till and conventional tillage by retaining residue cover in the interrow, and provides a competition-free zone for crop emergence (Vyn and Raimbault, 1993). Undisturbed cover crop mulch can be killed by herbicides or mechanical means. In herbicide-based systems, Mckeown et al. (1998) reported greater tomato yields in strip-tilled plots in 5 out of 6 years compared with conventional tillage, but concerns were raised about higher nematode populations and reduced numbers of harvests in strip-tilled plots. Additionally, bacterial speck (Pseudomonas syringae pv. tomato) and bacterial spot (Xanthomonas campestris pv. vesicatoria) were greater in 3 out of 6 years in strip-tilled tomatoes. In all organic vegetable crop systems where the prohibition of synthetic herbicides necessitates mechanical options, Creamer et al. (1996) demonstrated organic tomato yields in an undercut cover crop mixture of hairy vetch, rye, crimson clover, and barley were comparable to conventionally fertilized tomatoes. Wilson et al. (1982) reported satisfactory yields of corn and cowpea (Vigna unguiculata ssp. unguiculata) in mowed strips of a cover crop of a tropical legume (Stylosanthes guianensis).

Additional benefits from cover crops, incorporated or as mulch, can include interference with insect and disease spread, such as rye mulching in strip-tilled plots reducing potato leafhopper (Empoasca fabae) populations compared with conventional plots (Andow, 1991). Lower leafhopper numbers may have corresponded to host masking by the rye mulch or, in the case of snap beans, less preference for the reduced $\mathrm{N}$ content in strip-tilled snap beans (Bottenberg et al., 1999). White mold (Sclerotina sclerotiorum), a soil-borne fungal pathogen, was also reduced by the rye treatments. Mechanisms suggested by this effect include the physical barrier of the mulch minimizing contact between soil/pathogen and plant (Bottenberg et al., 1999) and enhanced microbiological attack of soil pathogens (Thurston, 1992). Loy et al. (1987), however, found higher populations of common stalk borer (Papaipema nebris) in striptilled plots compared with tilled plots.

To evaluate the effects of organic-compliant fertilizers and cover crops, a systems experiment was established in 1998 at the Iowa State University Muscatine Island Research Farm in Fruitland, Iowa, to compare bell pepper production under conventional and organic man- agement (Delate, 2002). Although the farm site was not certified organic, all organic practices were USDANOP compliant (U.S. Department of Agriculture, 2007b). The crop rotation for the experimental site was the pepper crop, preceded and succeeded by a fallow field of rye for one year, in accordance with NOP rules. A 5-m buffer zone of tilled ground was created around each plot, and conventional treatments were applied on calm days to prevent any synthetic chemical drift from conventional plots into organic plots. Treatments within the experiment consisted of combinations of two synthetic fertilizers and three compost-based organic fertilizers allowed in certified organic production. In addition to the organic fertilizers, effects of a cover crop of hairy vetch and rye were evaluated in the organic system. In the first phase of the experiment (1998-2000), pepper growth, harvest weight, and marketable fruit numbers were similar in conventional and organic production systems when $112 \mathrm{~kg} \cdot \mathrm{ha}^{-1} \mathrm{~N}$ was applied through synthetic fertilizer or compost (Delate et al., 2003). Strip-tillage and incorporation of cover crops before planting resulted in pepper yields equivalent to compost treatments in the first year, but pepper growth was significantly reduced in second-year strip-tilled plots (Delate et al., 2003). This study was undertaken to compare bell pepper field and postharvest performance due to production practices including organic and conventional soil amendments; to evaluate organic pepper production in tilled and strip-tilled cover crops; and to evaluate the effect of cover crops and organic fertilization on soil fertility in organic systems.

\section{Materials and methods}

The Iowa State University Muscatine Island Research Farm is located on Mississippi River bottomland soil in southeast Iowa. The soil type for the experiment was a well-drained Fruitland course sand, with a slope of $<5 \%$ and an average organic matter content of $<2.5 \%$. Field operations for the 3 years of the experiment (200103 ) are described in Table 1 . A cover crop mixture of organic hairy vetch and rye (Welter Seed, Onslow, IA) was seeded in organic plots in 
Table 1. Pepper system field operations in 2001-03 at the Muscatine Island Research Farm, Fruitland, IA.

\begin{tabular}{|c|c|c|c|}
\hline \multirow[b]{2}{*}{ Activity } & \multicolumn{3}{|c|}{ Year } \\
\hline & 2001 & 2002 & 2003 \\
\hline Hairy vetch/rye planted & 12 Sept. 2000 & 21 Sept. 2001 & 24 Sept. 2002 \\
\hline Soil sampling & 8 May; 11 Sept. & $\begin{array}{l}28 \text { May; } 12 \text { and } \\
26 \text { June; } 19 \text { Sept. }\end{array}$ & $\begin{array}{l}14 \text { May; } 13 \text { and } \\
27 \text { June; } 14 \text { May } 2004\end{array}$ \\
\hline Cover crop mowed & 21 May & l June & 5 June \\
\hline Conventional plots fertilized & 23 May & 30 May & 30 May \\
\hline Herbicide applied in conventional plots & 30 May & 8 June & 30 May \\
\hline Side-dress fertilizer in strip-tilled plots applied & $一^{\mathrm{z}}$ & 25 June & 25 June \\
\hline Rye straw mulch applied in strip-tilled plots & 16 July & 11 July & 14 July \\
\hline Plant performance sampling & $\begin{array}{l}18 \text { June; } 2 \text {, } \\
29 \text { July; } 2 \text { Aug. }\end{array}$ & $\begin{array}{l}25 \text { June; } 11 \text {, } \\
24 \text { July; } 6 \text { Aug. }\end{array}$ & 26 June; 14,28 July \\
\hline
\end{tabular}

${ }^{\mathrm{z}}$ Not applied.

September of each year preceding pepper production (12 to 24 Sept. 2000-02) at 67 and $101 \mathrm{~kg} \cdot \mathrm{ha}^{-1}$, respectively. The cover crop germinated in September, remained dormant throughout the winter, and began regrowth in the spring. Cover crop plots were treated as one of two systems: 1) incorporated (tilled): the hairy vetch/rye mixture was mowed when the rye reached heading stage (21 May to 5 June) and roto-tilled 2 to $10 \mathrm{~d}$ later to completely incorporate the mixture before pepper transplanting, or 2) strip-tilled: the vetch/ rye mixture was crushed with a cultipak, followed by a "strip-till system" of a disc coulter and chisel sweep acting as an undercutter, sweeping 20 to $25 \mathrm{~cm}$ under the cover crop to cut roots and loosen the soil under the mulch with minimum disturbance of the soil surface on the same day as cover crop incorporation. Passage of the disc coulter and chisel sweep left a 7.6-cm-wide strip down the center of the row into which peppers were transplanted. In 2002 and 2003, the strip-tilled plants were side-dressed with the $56 \mathrm{~kg} \cdot \mathrm{ha}^{-1} \mathrm{~N}$ organic fertilizer on 25 June to test the effect of an additional $\mathrm{N}$ application on striptilled plant growth.

'Red Knight' bell pepper seeds (Johnny's Selected Seeds, Albion, $\mathrm{ME}$ ) were planted in greenhouses in 72 -cell trays containing organic-compliant media (Sunshine LC-1 Mix ${ }^{\circledR}$; Sun-Gro Horticulture, Bellevue, WA) from 11 to $23 \mathrm{Apr}$. each year. At $18 \mathrm{~cm}$ of height, plants were mechanically transplanted into field plots at a $107-\mathrm{cm}$ row spacing and $46-\mathrm{cm}$ plant spacing from 1 to 13 June. The experimental design used in this study was a randomized complete block design with four replications. Each $25-\mathrm{m}^{2}$ plot contained 48 plants in four single rows for a total of 1728 plants in the experiment. Treatments examined in this experiment were representative of plant nutrient combinations used by conventional and organic growers in the midwestern United States. The goal of the fertilization program was to obtain similar rates of $\mathrm{N}$ in the organic and conventional system $\left(\approx 112 \mathrm{~kg} \cdot \mathrm{ha}^{-1}\right.$ $\mathrm{N})$. Calcium and sulfur application rates in specific conventional plots were matched to the concentrations of $21 \%$ calcium (Ca) and $17 \%$ sulfur $(\mathrm{S})$ in the gypsum applied in specific organic plots. Treatments consisted of the following combinations: Treatment 1 = organic control (no fertilization/no herbicides); Treatment 2 = organic fertilizer (Cinagro ${ }^{\mathrm{TM}}$; Midwest Bio- $\mathrm{Ag}^{\circledR}$, Blue Mounds, WI) applied to supply a full rate of 112 $\mathrm{kg} \cdot \mathrm{ha}^{-1} \mathrm{~N}$, preplant incorporated; Treatment 3 = half-rate organic fertilizer $\left(56 \mathrm{~kg} \cdot \mathrm{ha}^{-1} \mathrm{~N}\right)+$ gypsum at 560 $\mathrm{kg} \cdot \mathrm{ha}^{-1}$, all preplant incorporated; Treatment $4=$ organic fertilizer (112 kg.ha-1 N) + gypsum at 560 $\mathrm{kg} \cdot \mathrm{ha}^{-1}$, all preplant incorporated; Treatment 5 = hairy vetch $/$ rye cover crop mixture tilled into field before planting; Treatment 6 = hairy vetch/ rye cover crop mixture strip-tilled in field; Treatment $7=$ conventional control (no fertilizer, recommended herbicides); Treatment $8=$ conven- tional fertilizer (112 $\mathrm{kg} \cdot \mathrm{ha}^{-1} \mathrm{~N}$; recommended herbicides); and Treatment $9=$ conventional fertilizer (112 kg.ha ${ }^{-1} \mathrm{~N}$; recommended herbicides) + hydrated lime at $400 \mathrm{~kg} \cdot \mathrm{ha}^{-1}$ and elemental $S$ at $1112 \mathrm{~kg} \cdot \mathrm{ha}^{-1}$ to supply $\mathrm{Ca}$ and $\mathrm{S}$ equivalent to gypsum content. The conventional fertilizer was applied as a split application: 63 $\mathrm{kg} \cdot \mathrm{ha}^{-1} \mathrm{~N}, 63 \mathrm{~kg} \cdot \mathrm{ha}^{-1}$ of phosphorus $(\mathrm{P})$, and $197 \mathrm{~kg} \cdot \mathrm{ha}^{-1}$ of potassium $(\mathrm{K})$ were incorporated into plots from 23 to 30 May each year before transplanting peppers, and a side-dress application of $49 \mathrm{~kg} \cdot \mathrm{ha}^{-1} \mathrm{~N}$ was then applied at first flower. Trifluralin (Treflan ${ }^{\circledR}$; Dow AgroSciences, Indianapolis) was applied as a single application in the conventionally managed plots at $0.5 \mathrm{lb} /$ acre a.i. Insecticides were scheduled to be applied only if monitoring reports signified a need for treatment; no insecticides were applied in any year. Weeds were mechanically cultivated in the organic plots throughout the season, except in the hairy vetch/rye strip-tilled plots, where the cover crop was left as mulch between plant rows.

In 2002 and 2003, aboveground cover crop biomass was determined before mowing or incorporation from three randomly selected $1-\mathrm{m}^{2}$ samples in each cover crop plot. Plants were cut at soil level, placed in a forcedair dryer, dried at $60{ }^{\circ} \mathrm{C}$ for $5 \mathrm{~d}$, and weighed. Nitrogen content of the cover crop was determined in 2003 at the Soil and Plant Analysis Laboratory (Iowa State University, Department of Agronomy, Ames). If cover crop growth was deemed 
insufficient for full weed management in strip-tilled plots, based on emergence of weeds through cover crop residue, rye straw was applied as a mulch. The mulch application (7.6 $\mathrm{cm}$ deep) occurred in mid-July each year. Irrigation was applied as needed based on rainfall events. A core set of measurements was taken on 10 random plants/plot within the interior of the plot (40 plants/treatment) from June to August. Height of plants, number of leaves, and number of pepper fruit were recorded, along with disease incidence and numbers of harmful and beneficial insects. Pepper number/plant at maximum leaf height was recorded in July to determine early fruit set compared with fruit numbers at harvest. Pepper plants showing substantial disease symptoms were removed from plots after recording their numbers at each sampling period. Peppers were harvested from August to September by selecting all marketable fruit on 10 random plants/plot. In 2002 and 2003, numbers of culled fruit (peppers having sufficient damage to be unmarketable) were also counted from sampled plants in each plot at harvest. Fresh weights of fruit were recorded immediately after harvest. Blemish counts were calculated by counting the number of insect or disease lesions $\leq 2 \mathrm{~mm}$ in diameter on the pepper surface. At that period of time, peppers were considered marketable if lesions were $\leq 2 \mathrm{~mm}$ diameter; peppers with larger blemishes were discarded. After initial weighing, 24 unblemished peppers/ treatment/harvest were transferred to $10{ }^{\circ} \mathrm{C} / 70 \%$ relative humidity chambers in the Iowa State University Department of Horticulture in Ames for postharvest storage studies. Pepper fresh weight was recorded at 3,6 , and 9 weeks of storage. Evaluations were ended when peppers became unmarketable. All measurements were subjected to analysis of variance (ANOVA) and mean separation with Fisher's protected least significant differences (PLSD) test at $P \leq 0.05$ (SAS version 8.0; SAS Institute, Cary, $\mathrm{NC})$.

SoIl FerTility study. To monitor soil changes, particularly in the organic system throughout the experiment, soil samples were collected in cover crop plots before spring tillage on 8 May 2001, and in cover crop and organic fertilizer (112 $\mathrm{kg} \cdot \mathrm{ha}^{-1} \mathrm{~N}$ ) plots on the last harvest date of 11 Sept. 2001. In 2002, soils were sampled in cover crop plots preseason (28 May), pretransplanting (12 June), and 2 weeks post-transplanting (26 June) to determine soil fertility changes between cover crop incorporation and plant growth initiation. Soils were also sampled on the last harvest date (19 Sept.) as previously described. In 2003, soils were sampled in cover crops as in 2002: preseason (14 May), pretransplanting (13 June), and 2 weeks post-transplanting (27 June). An additional soil sampling was obtained on 13 May 2004 to determine overwintering effects in all plots.

For each sampling date, five cores were removed to a depth of 15 $\mathrm{cm}$ and combined into one composite sample for each plot. The composite samples were stored in plastic zip-lock bags and kept cool during transport to the laboratory. A 10 -g subsample of field-moist $8-\mathrm{mm}$-mesh sieved soil was extracted with $50 \mathrm{~mL}$ of $2 \mathrm{M}$ potassium chloride $(\mathrm{KCl})$, and inorganic $\mathrm{N}$ [nitrite and nitrate- $\mathrm{N}\left(\mathrm{NO}_{2}\right.$ $\left.+\mathrm{NO}_{3}\right)+$ ammonium-N $\left.\left(\mathrm{NH}_{4}-\mathrm{N}\right)\right]$ in the filtrate was quantified using flow injection technology (Lachat Instruments, Milwaukee). Soil water content was determined gravimetrically by oven-drying a 15 -g subsample of field-moist $8-\mathrm{mm}$-mesh sieved soil overnight at $105^{\circ} \mathrm{C}$. A subsample of field-moist 8 -mm-mesh sieved soil was pushed through a $2-\mathrm{mm}$-mesh sieve, air-dried, stored at room temperature, and later analyzed for $\mathrm{P}$, $\mathrm{K}, \mathrm{Ca}, \mathrm{pH}$, and electrical conductivity (EC). A 5-g subsample of the airdried, 2-mm-mesh-sieved material was ground $(<250 \mu \mathrm{m})$ and used to determine total organic carbon and total N. Phosphorus concentrations (Bray-P) (Knudsen and Beegle, 1988) were measured colormetrically using ascorbic acid-ammonium molybdate reagents. Soil pH (Eckert, 1988) and EC (Dahnke and Whitney, 1988) were measured using a 1 soil:2 water ratio. Total organic carbon after removal of carbonates with $1 \mathrm{M}$ sulfuric acid $\left(\mathrm{H}_{2} \mathrm{SO}_{4}\right)$ and total $\mathrm{N}$ were quantified by dry combustion using a Carlo-Erba NA 1500 NCS elemental analyzer (Haake Buchler Instruments, Paterson, NJ). All analyses were conducted at the USDA-Agriculture Research Service National
Soil Tilth Laboratory at Ames, Iowa, and the Soil and Plant Analysis Laboratory. In addition to ANOVA, soil fertility results were analyzed through single-df contrasts (SAS, version 8.0).

\section{Results}

Crop performance. In 2001, pepper plant height was greater in the organic fertilizer treatments $\left(112 \mathrm{~kg} \cdot \mathrm{ha}^{-1} \mathrm{~N}\right)$, with or without gypsum, the conventional fertilizer treatment, and the hairy vetch/rye strip-tilled treatment, compared with the organic or conventional control or tilled cover (Table 2). Plant height in the incorporated vetch/rye treatment was lower than the strip-tilled treatment. Plants in the $112 \mathrm{~kg} \cdot \mathrm{ha}^{-1}$ $\mathrm{N}$ organic treatment were taller than the $56 \mathrm{~kg} \cdot \mathrm{ha}^{-1} \mathrm{~N}$ organic fertilizer treatment. Leaf number at maximum plant height was greatest in the conventional fertilizer treatment, with and without $\mathrm{Ca} / \mathrm{S}$. Plants in the organic fertilizer treatment (112 $\mathrm{kg} \cdot \mathrm{ha}^{-1} \mathrm{~N}$ ) were second in leaf number to conventional treatments, with plants in the organic control and in both hairy vetch/rye plots having the least amount of leaf production. Fruit numbers at maximum plant height were significantly greater in the organic fertilizer treatments (at 56 and $112 \mathrm{~kg} \cdot \mathrm{ha}^{-1} \mathrm{~N}$ ), and in the conventional fertilizer with $\mathrm{Ca} / \mathrm{S}$ treatment, compared with other treatments. Gypsum applications did not increase fruit numbers over organic fertilizer alone. Lowest fruit numbers were produced in the cover crop treatments.

In 2002, the tallest plants were in the organic fertilizer $\left(112 \mathrm{~kg} \cdot \mathrm{ha}^{-1} \mathrm{~N}\right)$ and in the conventional fertilizer treatments, with and without $\mathrm{Ca} / \mathrm{S}$ (Table 2). Plant height in the conventional treatments was equivalent to the organic fertilizer $\left(112 \mathrm{~kg} \cdot \mathrm{ha}^{-1} \mathrm{~N}\right.$ and $56 \mathrm{~kg} \cdot \mathrm{ha}^{-1} \mathrm{~N}$ ) with gypsum treatment and the strip-tilled treatment plus organic fertilizer side-dress (Table 2). The addition of the 56 $\mathrm{kg} \cdot \mathrm{ha}^{-1} \mathrm{~N}$ side-dress application in strip-tilled plots led to an improvement in pepper productivity, and because of this result, a side-dress application was added to future protocols. Plant height in the incorporated hairy vetch/rye treatment was equivalent to the organic and conventional controls. Leaf number was greatest in the conventional 
Table 2. Pepper plant growth in 2001-03 at the Muscatine Island Research Farm, Fruitland, IA.

\begin{tabular}{|c|c|c|c|c|c|c|c|c|c|}
\hline \multirow[b]{2}{*}{ Treatment } & \multicolumn{3}{|c|}{2001} & \multicolumn{3}{|c|}{2002} & \multicolumn{3}{|c|}{2003} \\
\hline & $\begin{array}{c}\text { Plant } \\
\text { ht }(\mathrm{cm})^{z}\end{array}$ & $\begin{array}{c}\text { Leaves } \\
\text { (no./plant) }\end{array}$ & $\begin{array}{c}\text { Peppers } \\
\text { (no./plant) }\end{array}$ & $\begin{array}{c}\text { Plant } \\
\text { ht }(\mathrm{cm})\end{array}$ & $\begin{array}{c}\text { Leaves } \\
\text { (no./plant) }\end{array}$ & $\begin{array}{c}\text { Peppers } \\
\text { (no./plant) }\end{array}$ & $\begin{array}{c}\text { Plant } \\
\text { ht }(\mathrm{cm})\end{array}$ & $\begin{array}{c}\text { Leaves } \\
\text { (no./plant) }\end{array}$ & $\begin{array}{c}\text { Peppers } \\
\text { (no./plant) }\end{array}$ \\
\hline Organic control & $45.5 \mathrm{~d}^{\mathrm{y}}$ & $27.0 \mathrm{e}$ & $5.5 \mathrm{bc}$ & $42.4 \mathrm{c}$ & $48.2 \mathrm{cde}$ & $3.8 \mathrm{~cd}$ & $35.1 \mathrm{~b}$ & $53.3 \mathrm{~b}$ & $2.3 \mathrm{ab}$ \\
\hline \multicolumn{10}{|l|}{ Organic fertilizer } \\
\hline$\left(112 \mathrm{~kg} \cdot \mathrm{ha}^{-1} \mathrm{~N}\right)^{\mathrm{x}}$ & $52.5 \mathrm{a}$ & $52.6 b$ & $6.3 \mathrm{a}$ & $51.5 \mathrm{a}$ & $67.8 \mathrm{ab}$ & $6.3 \mathrm{a}$ & $38.2 \mathrm{a}$ & $59.7 \mathrm{ab}$ & $2.3 \mathrm{ab}$ \\
\hline $\begin{array}{l}\text { Organic fertilizer } \\
\left(56 \mathrm{~kg} \cdot \mathrm{ha}^{-1} \mathrm{~N}\right)+ \\
\text { gypsum }\left(560 \mathrm{~kg} \cdot \mathrm{ha}^{-1}\right)\end{array}$ & $48.8 \mathrm{bc}$ & $41.2 \mathrm{c}$ & $6.4 \mathrm{a}$ & $44.8 \mathrm{bc}$ & $52.2 \mathrm{c}$ & $4.5 \mathrm{bc}$ & $37.7 \mathrm{a}$ & $61.8 \mathrm{a}$ & $2.7 \mathrm{a}$ \\
\hline $\begin{array}{l}\text { Organic fertilizer } \\
\left(112 \mathrm{~kg} \cdot \mathrm{ha}^{-1} \mathrm{~N}\right)+ \\
\text { gypsum }\left(560 \mathrm{~kg} \cdot \mathrm{ha}^{-1}\right)\end{array}$ & $49.9 \mathrm{ab}$ & $41.8 \mathrm{c}$ & $6.1 \mathrm{ab}$ & $47.6 \mathrm{~b}$ & $63.2 b$ & $5.5 a$ & $38.1 \mathrm{a}$ & $59.9 \mathrm{ab}$ & $2.4 \mathrm{ab}$ \\
\hline Hairy vetch/rye tilled & $46.2 \mathrm{~cd}$ & $28.8 \mathrm{e}$ & $5.0 \mathrm{~cd}$ & $43.6 \mathrm{c}$ & $48.6 \mathrm{~cd}$ & $3.7 \mathrm{~cd}$ & $37.0 \mathrm{ab}$ & $56.4 \mathrm{ab}$ & $1.5 b$ \\
\hline $\begin{array}{l}\text { Hairy vetch/rye } \\
\text { strip-tilled }\end{array}$ & $50.5 \mathrm{ab}$ & $28.6 \mathrm{e}$ & $4.4 \mathrm{~d}$ & - & - & - & - & - & - \\
\hline Conventional control & $46.2 \mathrm{~cd}$ & $35.1 d$ & $5.2 \mathrm{c}$ & $41.7 \mathrm{c}$ & $42.4 \mathrm{de}$ & $2.9 \mathrm{~d}$ & $29.5 c$ & 49.1c & $2.8 \mathrm{a}$ \\
\hline Conventional fertilizer & $50.6 \mathrm{ab}$ & $59.1 \mathrm{a}$ & $5.2 \mathrm{c}$ & $48.8 \mathrm{ab}$ & $67.1 \mathrm{ab}$ & $4.1 \mathrm{c}$ & $31.2 \mathrm{c}$ & $46.5 \mathrm{c}$ & $2.2 \mathrm{ab}$ \\
\hline Conventional fertilizer, & & & & & & & & & \\
\hline lime and sulfur & $49.0 \mathrm{~b}$ & $59.1 \mathrm{a}$ & $5.7 \mathrm{abc}$ & $48.3 \mathrm{ab}$ & $74.3 \mathrm{a}$ & $4.0 \mathrm{c}$ & $30.1 \mathrm{c}$ & $44.5 \mathrm{c}$ & $2.5 \mathrm{ab}$ \\
\hline $\operatorname{LSD}(0.05)^{\mathrm{w}}$ & 2.8 & 5.1 & 0.8 & 3.3 & 9.7 & 1.0 & 2.3 & 7.8 & 1.0 \\
\hline
\end{tabular}

${ }^{\mathrm{z}} 1 \mathrm{~cm}=0.3937$ inch.

${ }^{y}$ Means within columns followed by the same letter are not significantly different at $P \leq 0.05$; NS = nonsignificant.

${ }^{\mathrm{x}} \mathrm{l} \mathrm{kg} \cdot \mathrm{ha}^{-1}=0.8922 \mathrm{lb} /$ acre.

${ }^{\text {w }}$ LS $(0.05)=$ least significant difference at $P=0.05$

fertilizer treatment with $\mathrm{Ca} / \mathrm{S}$, the conventional fertilizer alone, and in the organic fertilizer $\left(112 \mathrm{~kg} \cdot \mathrm{ha}^{-1} \mathrm{~N}\right)$ treatment. Plants in the $112 \mathrm{~kg} \cdot \mathrm{ha}^{-1}$ $\mathrm{N}$ organic fertilizer with gypsum treatment had leaf numbers similar to the previous two treatments. Despite lower plant height, the tilled cover crop treatment produced a greater number of leaves than the strip-tilled treatment (Table 2). Plants producing the greatest number of fruit in July were in the organic fertilizer treatments of $112 \mathrm{~kg} \cdot \mathrm{ha}^{-1} \mathrm{~N}$, with and without gypsum (Table 2). There were no differences in fruit numbers between the conventional fertilizer treatments and the lower organic fertilizer rate plus gypsum treatment. Fruit numbers were similar in the two cover crop treatments in 2002 , but in the hairy vetch/rye strip-tilled plots, fruit numbers were equivalent to the conventional control plots.

In 2003, all organic plants were taller than plants receiving conventional treatments (Table 2). There were no differences in plant height among the $112 \mathrm{~kg} \cdot \mathrm{ha}^{-1} \mathrm{~N}$ organic fertilizer, with and without gypsum; $56 \mathrm{~kg} \cdot \mathrm{ha}^{-1} \mathrm{~N}$ with gypsum; and in both hairy vetch/rye treatments. Plants in the incorporated hairy vetch/rye treatment were an equivalent height as plants in the organic control. Leaf number was also greater on plants in all organic treatments compared with those in conventional treatments (Table 2). Pepper number was similar in seven of the nine treatments in July, but both cover crop treatments had lower pepper numbers than the organic $56 \mathrm{~kg} \cdot \mathrm{ha}^{-1} \mathrm{~N}$ with gypsum treatment (Table 2).

In the first year, pepper yield was similar in both conventional plots (averaging 24,299 $\mathrm{kg} \cdot \mathrm{ha}^{-1}$ ) and organic plots fertilized with 112 $\mathrm{kg} \cdot \mathrm{ha}^{-1} \mathrm{~N}$, with and without gypsum (averaging 26,295 kg.ha ${ }^{-1}$ ) (Table 3). Yields in the $56 \mathrm{~kg} \cdot \mathrm{ha}^{-1} \mathrm{~N}$ organic fertilizer treatment were equivalent to the higher organic fertilizer rate. Strip-tilled hairy vetch/rye plots, without additional fertilization, contained some of the lowest yielding plants, along with the conventional and organic control plots. When the hairy vetch/rye was incorporated, yields were equivalent to the organic fertilizer treatments, but lower than the conventional fertilizer with $\mathrm{Ca} / \mathrm{S}$ treatment. The number of peppers at harvest ranged from 124,378 peppers/ha in the conventional control to 213,035 peppers/ha in the conventional fertilizer with $\mathrm{Ca} / \mathrm{S}$ treatment with no significant differences among treatments (Table 3 ). Organic fertilizer $\left(112 \mathrm{~kg} \cdot \mathrm{ha}^{-1} \mathrm{~N}\right)$ plants averaged 162,251 peppers/ha compared with 163,111 peppers/ha in the conventional fertilizer treatment. Average pepper fruit weight $(172 \mathrm{~g})$ in the organic $112 \mathrm{~kg} \cdot \mathrm{ha}^{-1} \mathrm{~N}$ treatment was equivalent to that of $156 \mathrm{~g}$ in the conventional fertilizer treatment (data not shown).

Contrary to 2001 results, pepper yields from all organic and conventional treatments were similar in 2002 (Table 3 ). The average yield of the $112 \mathrm{~kg} \cdot \mathrm{ha}^{-1} \mathrm{~N}$ organic fertilizer treatment was $15,572 \mathrm{~kg} \cdot \mathrm{ha}^{-1}$ compared with $15,680 \mathrm{~kg} \cdot \mathrm{ha}^{-1}$ in the conventional fertilizer treatment. With the additional $\mathrm{N}$ side-dress application, yields in the strip-tilled treatment averaged $14,833 \mathrm{~kg} \cdot \mathrm{ha}^{-1}$ compared with 12,621 in the tilled cover crop treatment (Table 3 ). Similar to yield results, pepper numbers at harvest were equivalent among treatments, and averaged 101,873 across the two control plots compared with 


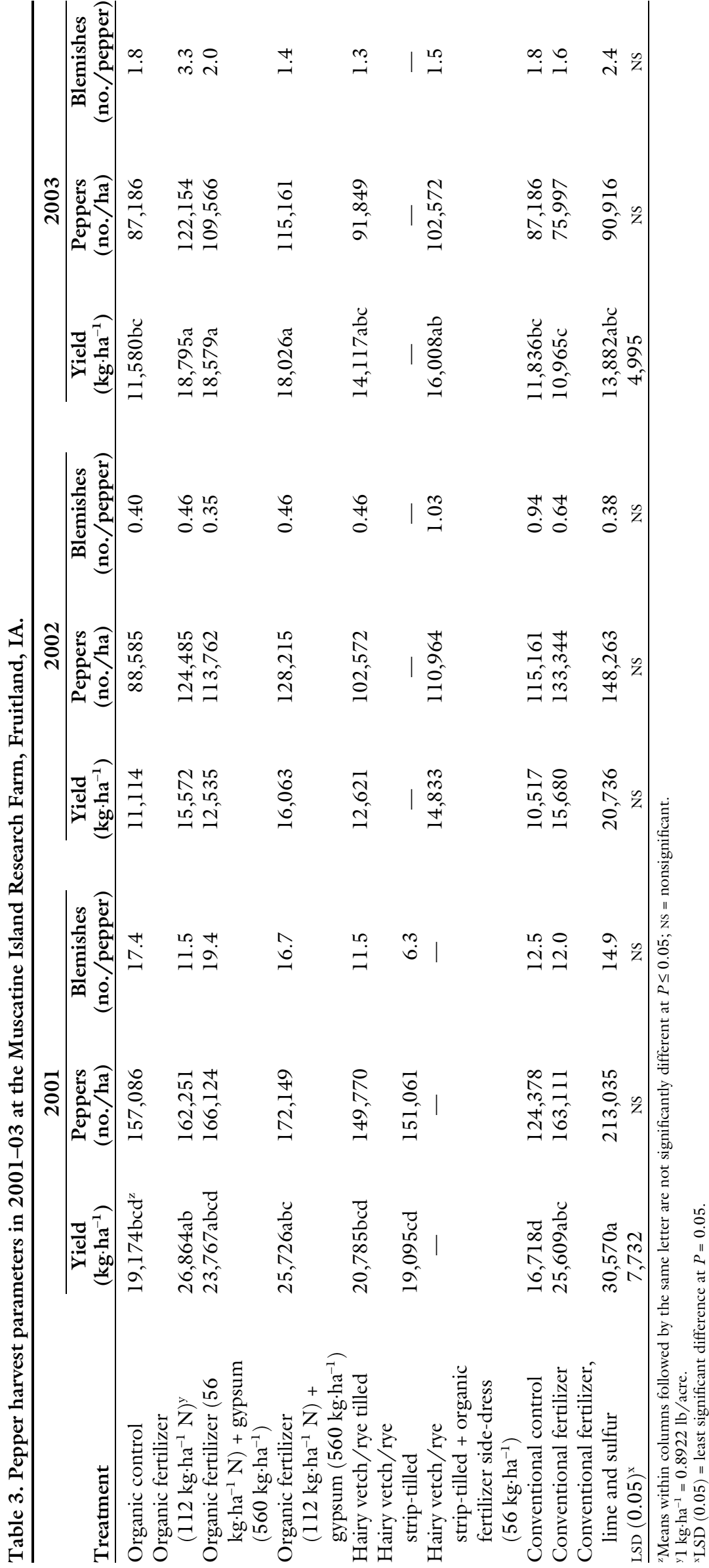

148,263 peppers/ha in the conventional fertilizer with $\mathrm{Ca} / \mathrm{S}$ plots (Table 3). Plants in the $112 \mathrm{~kg} \cdot \mathrm{ha}^{-1}$ $\mathrm{N}$ organic fertilizer treatment averaged 124,485 peppers/ha compared with an average of 133,344 in the conventional fertilizer treatment. Across the two cover crop treatments, pepper numbers at harvest averaged 106,768 peppers/ha. Average pepper weight in 2002 was $132 \mathrm{~g}$ with no differences among treatments (data not shown).

In 2003, organic treatment yields (excluding the control plots) averaged $17,105 \mathrm{~kg} \cdot \mathrm{ha}^{-1}$ and conventional treatments averaged 12,424 $\mathrm{kg} \cdot \mathrm{ha}^{-1}$, with conventional fertilizer plus $\mathrm{Ca} / \mathrm{S}$ treatment yields equivalent to organic fertilizer and cover crop treatments (Table 3 ). The additional $\mathrm{N}$ side-dress application in the striptilled treatment did not improve yields over the incorporated cover crop treatment. There were no differences in the number of peppers at harvest among all treatments, averaging 122,154 peppers/ha in the organic fertilizer treatment and 75,997 peppers/ha in the conventional fertilizer treatment (Table 3). Average pepper weight across treatments was $15 \mathrm{l}$ g, with no differences among treatments (data not shown).

Pest InCidence. Insect pests [green peach aphid (Myzus persicae) and corn borer (Ostrinia nubilalis)] were observed throughout the experiment, but did not reach economic threshold levels, and no differences in populations were observed among treatments in 2001 (Table 4). Beneficial insects, primarily ladybeetles (Coccinellidae), lacewings (Chrysopidae), and spiders (Salticidae), were also present in all plots, but because of low insect pest numbers, significant differences among treatments did not occur in the first year. Damping-off (Rhizoctonia solani) disease symptoms were observed in greater amounts in the strip-tilled plots, where up to $15 \%$ of plants were infected. Despite low numbers of insect pests in the field, insect and disease damage (as blemishes at harvest) ranged from six blemishes/pepper in the hairy vetch/rye strip-tilled treatment to 17 in the organic control, but because of high variability, there were no significant differences among treatments (Table 3). Striptilled plants were among the most 


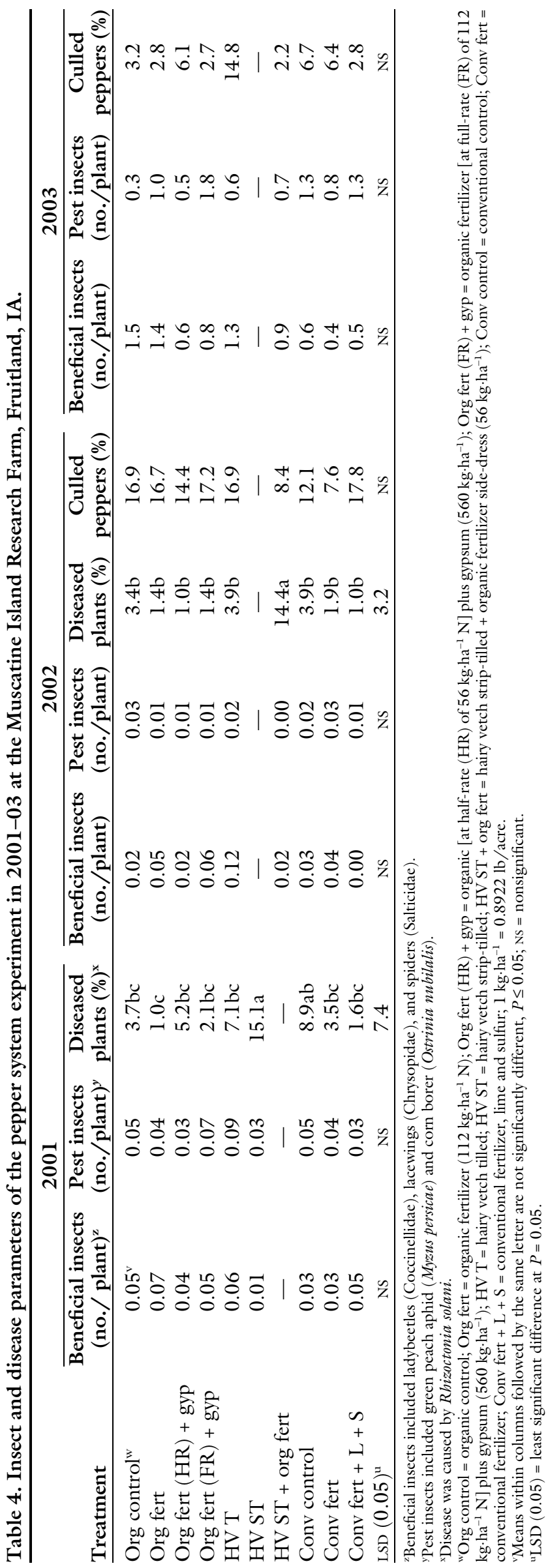

diseased plants early in the growing season, but fruit from these plots had an average of six blemishes/pepper at harvest, possibly because of the timely elimination of diseased plants in the field.

No differences were observed in pest or beneficial insect populations among treatments in 2002 and in 2003 (Table 4). There were significantly greater numbers of diseased plants removed from the strip-tilled hairy vetch/rye plots in 2002, averaging $14 \%$ (Table 4 ). All other treatments were similar and averaged $2.2 \%$ of plants with diseases. In 2003, disease incidence was low and no disease data were taken from plots during the growing season. In 2002 and 2003, numbers of culled fruit were similar among treatments, and ranged from $7.6 \%$ in the conventional fertilizer to $17.8 \%$ in the conventional fertilizer with $\mathrm{Ca} / \mathrm{S}$ treatment in 2002 , and $2.7 \%$ in the hairy vetch/rye tilled treatment to $14.9 \%$ in the hairy vetch/rye strip-tilled treatment in 2003 (Table 4). Blemishes on harvested peppers were minimal in 2002, averaging $<1$ blemish/pepper across all treatments (Table 3 ). There were also no differences in blemished peppers among treatments in 2003 , with blemishes ranging from 1.3 to 3.3 per fruit (Table 3).

Postharvest performance. Pepper weight loss after 6 weeks of postharvest storage was similar among treatments for all years of the experiment (Fig. 1). Average weight loss ranged from $14.3 \%$ in the hairy vetch/rye strip-tilled fruit to $18.4 \%$ in the organic control at 6 weeks.

COVER CROP PERFORMANCE. BiOmass accumulation before mowing was similar across the two hairy vetch/rye treatments in 2002 and in 2003 , averaging $3,966 \mathrm{~kg} \cdot \mathrm{ha}^{-1}$ in 2002 and $10,045 \mathrm{~kg} \cdot \mathrm{ha}^{-1}$ in 2003 (data not shown). Nitrogen content (2.2\%) was also similar between treatments (data not shown).

SOIL FERTILITY STUDY: Postharvest SOIL FerTility. Soil organic carbon (C) content, inorganic $\mathrm{N}$, Bray $\mathrm{P}, \mathrm{EC}$, and $\mathrm{pH}$ were not significantly different in the hairy vetch/rye treatments relative to the other organic treatments over the course of the experiment (Table 5). Total soil $\mathrm{C}$ in the organic fertilizer treatment was higher than the conventional fertilizer treatment after the 


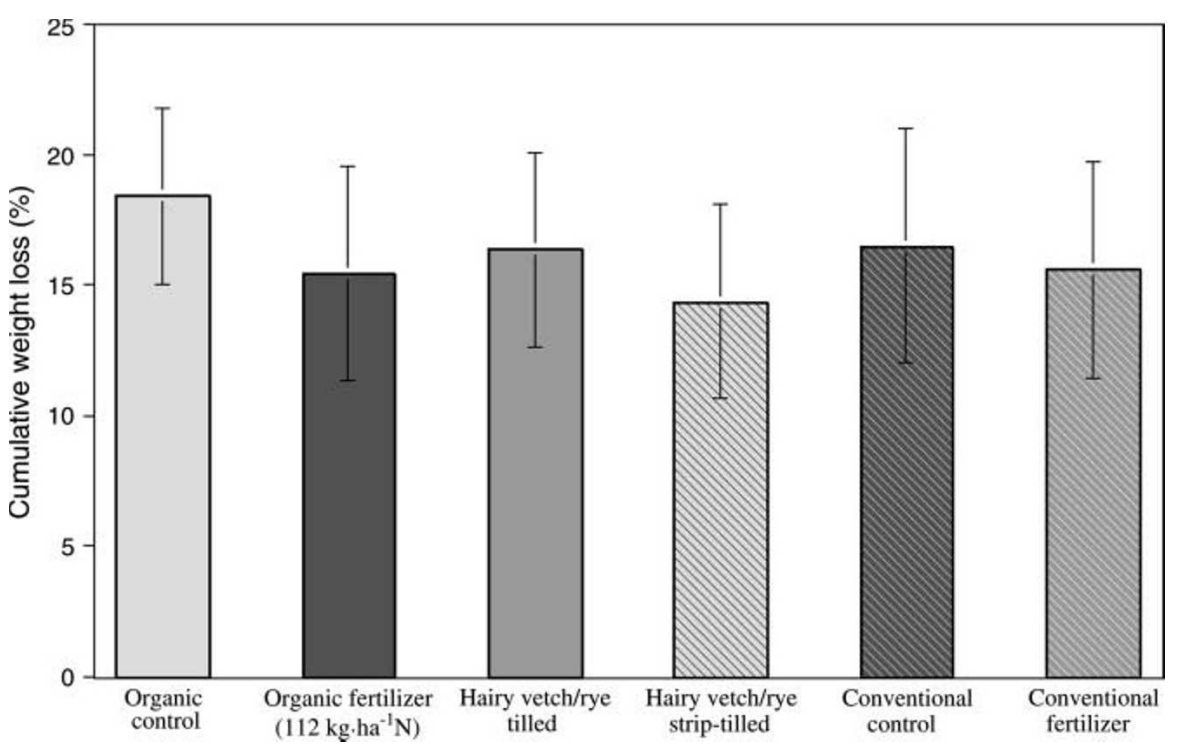

Fig. 1. Effect of treatment on pepper postharvest weight loss after 6 weeks of storage at $10{ }^{\circ} \mathrm{C}\left(50.0^{\circ} \mathrm{F}\right)$ and $70 \%$ relative humidity. Treatments were $\square$ Organic control, $\square$ Organic fertilizer $\left[112 \mathrm{~kg} \cdot \mathrm{ha}^{-1}(99.9 \mathrm{lb} /\right.$ acre $\left.) \mathrm{N}\right], \square$ Hairy vetch/rye tilled,

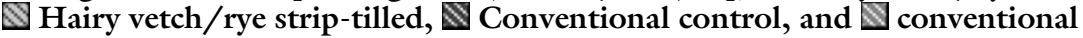
fertilizer. Bars represent the standard error of the mean.

2003 season, suggesting that relatively available organic $\mathrm{C}$ was accumulating compared with the conventional systems (Table 5). Total soil $\mathrm{N}$ content was higher in the incorporated hairy vetch/rye than in the strip-tilled treatment after harvest in 2001 (Table 5). Total soil $\mathrm{N}$ in the organic fertilizer treatment was equivalent to the incorporated hairy vetch/rye in all years (Table 5 ). This indicates that incorporation of hairy vetch/rye can help maintain soil $\mathrm{N}$ through the end of the growing season in pepper production systems, even in the absence of organic fertility amendments. In general, soil fertility in organic pepper plots was equal to, or greater than, that in conventionally produced peppers (Table 5).

SPRING SOIL FERTILITY IN COVER CROP TREATMENTS. Before hairy vetch/rye incorporation in May of each year, residual soil inorganic $\mathrm{N}$ was not different among treatments, except that in 2001 , soil nitrate- $\mathrm{N}$ in the incorporated hairy vetch/rye treatment was significantly lower than the organic control or the strip-tilled treatments (Table 6). Soil nitrate-N was significantly higher after hairy vetch/rye incorporation in June 2002 and 2003 compared with preincorporation soil nitrate levels (Table 6). However, soil nitrate-N was also significantly greater in June than in May in the organic control treatment for both years, indicating soil mineralization in the absence of cover crops.

Single-df contrasts (SAS, version 8.0) showed that in 2002 , the incorporated hairy vetch/rye treatment had greater soil nitrate- $\mathrm{N}$ than the organic control on 12 June $(\mathrm{F}=7.55$, $P=0.0115)$ and on 25 June $(\mathrm{F}=$ $21.15, P=0.0001$ ), but a higher soil nitrate- $\mathrm{N}$ response in the strip-tilled treatment was determined in the 25 June sampling $(\mathrm{F}=17.40, P=$ $0.0004)$. There was a trend toward increasing soil nitrate- $\mathrm{N}$ levels for both cover crop treatments on 25 June compared with 12 June in 2002 (hairy vetch/rye incorporated: $\mathrm{F}=3.43, P=0.0770$ ), but significant differences were observed only for the strip-tilled treatment $(\mathrm{F}=13.41, P=$ $0.0013)$. There were no pre- and postincorporation differences in soil ammonium-N in 2002. In 2003, post-hairy vetch/rye incorporation levels of soil nitrate $\mathrm{N}(\mathrm{F}=49.04, P$ $<0.0001)$ and ammonium- $\mathrm{N}(\mathrm{F}=$ $14.85, P=0.0009)$ were greater than on 14 May for the incorporated hairy vetch/rye treatment. The postincorporation levels of soil nitrate- $\mathrm{N}(\mathrm{F}=$ 9.82, $P=0.0045)$ and ammonium$\mathrm{N}(\mathrm{F}=8.87, P=0.0069)$ were also greater than May levels for the striptilled treatment. Soil nitrate-N was not different for either cover crop treatment on 26 June compared with 13 June 2003. The organic control also had more soil nitrate- $\mathrm{N}(\mathrm{F}=$ 5.97, $P=0.0223)$ and ammonium$\mathrm{N}(\mathrm{F}=4.69, P=0.0415)$ on 13 June than on 14 May.

The soil fertility data clearly show that soil inorganic $\mathrm{N}$ sources, and especially soil nitrate- $\mathrm{N}$, increased as a result of incorporation of hairy vetch/rye. However, the pattern of $\mathrm{N}$ release from the incorporated hairy vetch/rye appeared to vary between years and plots. Because the inorganic $\mathrm{N}$ in the top $15 \mathrm{~cm}$ of soil also increased in the organic control plots from May to June, this amount was deducted from the increase in soil inorganic $\mathrm{N}$ in the cover crop treatments postincorporation. Greater differences were observed for the incorporated versus strip-tilled hairy vetch/rye treatment, and the relative difference appeared to be consistent from year to year. One month after complete hairy vetch/rye incorporation in 2002, soil in the 0 to $15 \mathrm{~cm}$ depth increment contained $2.5 \mathrm{~kg} \cdot \mathrm{ha}^{-1}$ more inorganic $\mathrm{N}$ than before incorporation. Strip-tillage inorganic $\mathrm{N}$ content in the same increment after tillage was $1.5 \mathrm{~kg} \cdot \mathrm{ha}^{-1} \mathrm{~N}$ greater than was preincorporation levels. The magnitude of change in inorganic $\mathrm{N}$ at the 0 to $15 \mathrm{~cm}$ depth after vetch incorporation in 2003 appeared to be less than in 2002, but complete incorporation still resulted in a greater change $\left(1.1 \mathrm{~kg} \cdot \mathrm{ha}^{-1} \mathrm{~N}\right)$ in inorganic $\mathrm{N}$ than strip-tillage $\left(0.1 \mathrm{~kg} \cdot \mathrm{ha}^{-1} \mathrm{~N}\right)$.

\section{Discussion}

With the continuing 20\% annual organic industry growth rate, organic agriculture holds much promise for vegetable producers interested in gaining premium prices for their crops while lowering input costs (Dimitri and Greene, 2003). Lower organic yields have been associated with slower $\mathrm{N}$ release from organic amendments compared with synthetic fertilizers (MacRae et al., 1993), but results from this experiment demonstrated the feasibility of producing bell peppers in an organic system with comparable productivity to conventional peppers. These results compare with the first phase of this experiment where conventional and organic pepper growth and yields were similar when 112 $\mathrm{kg} \cdot \mathrm{ha}^{-1} \mathrm{~N}$ was provided through 


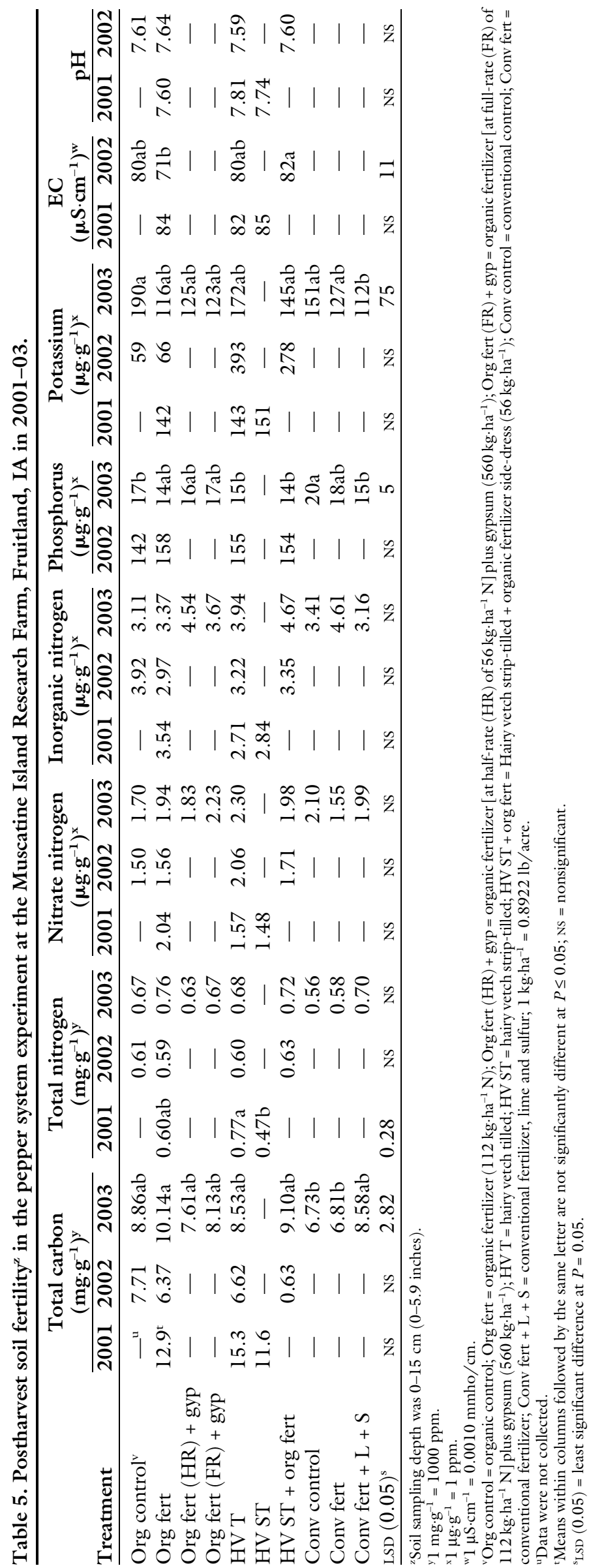

synthetic fertilizer in the conventional system or compost-based fertilizer in the organic system (Delate et al., 2003). Contrary to previous research (Delate et al., 2003), increasing the organic fertilizer rate from 56 to 112 $\mathrm{kg} \cdot \mathrm{ha}^{-1} \mathrm{~N}$ did not lead to an increase in yield, pepper number, or individual pepper weight. These results indicate that $\mathrm{N}$ supplementation as low as $\mathbf{5 6}$ $\mathrm{kg} \cdot \mathrm{ha}^{-1} \mathrm{~N}$ from carbon-based organic amendments may be sufficient for organic pepper production. Our limited knowledge of the underlying mechanisms operating in organic farming systems (Høgh-Jensen, 1998) includes understanding the interactions between beneficial soil microbial populations and nutrients present in manure-based organic fertilizers and in cover crops. High organic matter inputs in soil, such as compost and cover crops, have been previously shown to create greater levels of labile C sources, microbial activity, and $\mathrm{N}$ supplying capacity compared with conventional systems (Gunapala and Scow, 1998; Kramer et al., 2002). Organic-amended soils in other experiments have been shown to have twice the level of $\mathrm{N}$ as conventional soils (Burger and Jackson, 2003). This effect was demonstrated in this experiment where the $\mathrm{N}$ supply in soil remained high in organic plots throughout the growing season. The addition of $\mathrm{Ca}$ and $\mathrm{S}$ to conventional or organic fertilizer treatments did not lead to an increase in plant growth, yield, or postharvest storage, similar to previous research (Delate et al., 2003). Unless soil testing specifies a deficiency, use of these products may be unnecessary.

Results from the cover crop treatments were consistent with previous research. In the initial phase of the experiment, strip-tillage resulted in reduced pepper growth and yield compared with organic and conventional fertilizer treatments in 2 out of 3 years (Delate et al., 2003), similar to Bottenberg et al. (1999), where snap bean yields from plants in strip-tilled plots were $80 \%$ of plants under conventional cultivation. The additional $56 \mathrm{~kg} \cdot \mathrm{ha}^{-1} \mathrm{~N}$ side-dress application in strip-tilled plots did result in a yield increase, when strip-tilled yields were equivalent to conventional and organic fertilizer treatments, similar to the yield increase observed in tomato plots when $83 \mathrm{~kg} \cdot \mathrm{ha}^{-1} \mathrm{~N}$ was 
Table 6. Soil inorganic nitrogen, and pre- and postcover crop incorporation ${ }^{z}$ in the pepper system experiment at the Muscatine Island Research Farm, Fruitland, IA in 2001-03.

\begin{tabular}{|c|c|c|c|c|c|c|}
\hline \multirow[b]{2}{*}{ Sampling time } & \multicolumn{3}{|c|}{$\begin{array}{l}\text { Nitrate nitrogen } \\
\left(\mu \mathrm{g} \cdot \mathrm{g}^{-1}\right)^{\mathrm{y}}\end{array}$} & \multicolumn{3}{|c|}{$\begin{array}{l}\text { Ammonium nitrogen } \\
\left(\mu \mathrm{g} \cdot \mathrm{g}^{-1}\right)^{\mathrm{y}}\end{array}$} \\
\hline & 2001 & 2002 & 2003 & 2001 & 2002 & 2003 \\
\hline \multicolumn{7}{|l|}{ Preincorporation } \\
\hline Org control ${ }^{x}$ & $2.38 \mathrm{a}^{\mathrm{w}}$ & $3.42 \mathrm{c}$ & $1.05 \mathrm{~b}$ & 4.81 & 2.50 & $0.17 b$ \\
\hline HV T & $1.50 \mathrm{~b}$ & $0.61 \mathrm{c}$ & $0.42 b$ & 14.35 & 2.55 & $0.28 b$ \\
\hline HV ST & $1.67 \mathrm{ab}$ & $0.61 \mathrm{c}$ & $0.32 b$ & 4.88 & 1.44 & $0.29 b$ \\
\hline \multicolumn{7}{|l|}{ Pre-transplant } \\
\hline Org control & $一^{\mathrm{v}}$ & $4.07 \mathrm{~b}$ & $2.43 \mathrm{a}$ & - & 2.21 & $1.12 \mathrm{a}$ \\
\hline HV T & - & $4.70 \mathrm{~b}$ & $4.38 \mathrm{a}$ & - & 3.40 & $1.97 \mathrm{a}$ \\
\hline HV ST & - & $1.63 \mathrm{~b}$ & $2.09 \mathrm{a}$ & - & 3.20 & $1.59 \mathrm{a}$ \\
\hline \multicolumn{7}{|c|}{2 weeks post-transplant } \\
\hline Org control & - & $5.53 a$ & $2.87 \mathrm{a}$ & - & 1.47 & $0.19 b$ \\
\hline $\mathrm{HV} \mathrm{T}$ & - & $7.46 \mathrm{a}$ & $3.87 \mathrm{a}$ & - & 2.93 & $0.27 b$ \\
\hline HV ST & - & $7.08 \mathrm{a}$ & $2.57 \mathrm{a}$ & - & 0.84 & $0.44 \mathrm{~b}$ \\
\hline $\operatorname{LSD}(0.05)^{\mathrm{u}}$ & 0.77 & 1.90 & 0.76 & NS & NS & 0.48 \\
\hline
\end{tabular}

${ }^{2}$ Soil sampling depth was $0-15 \mathrm{~cm}(0-5.9$ inches $)$.

${ }^{y} 1 \mu \mathrm{g} \cdot \mathrm{g}^{-1}=1 \mathrm{ppm}$

${ }^{\mathrm{x}}$ Org control = organic control; HV T $=$ hairy vetch tilled; HV ST $=$ hairy vetch strip-tilled.

wMeans within columns followed by the same letter are not significantly different at $P \leq 0.05$; NS = nonsignificant. "Data were not collected.

${ }^{\mathrm{u}} \mathrm{LSD}(0.05)=$ least significant difference at $P=0.05$

applied to no-tilled cover crop plots at the time of planting (Abdul-Baki and Teasdale, 1997b). Average yields in the incorporated hairy vetch/rye treatment were intermediate to the organic fertilizer $\left(56 \mathrm{~kg} \cdot \mathrm{ha}^{-1} \mathrm{~N}\right)$ with gypsum and the $112 \mathrm{~kg} \cdot \mathrm{ha}^{-1} \mathrm{~N}$ treatment, indicating an $\mathrm{N}$ contribution of 56 to $112 \mathrm{~kg} \cdot \mathrm{ha}^{-1}$ from the incorporated hairy vetch/rye. Skarphol et al. (1987) suggested a contribution of $90 \mathrm{~kg} \cdot \mathrm{ha}^{-1} \mathrm{~N}$ from hairy vetch, crimson clover, or Austrian winter pea (Pisum satioum), wheres Griffin et al. (2000) estimated a contribution of between 78 to $156 \mathrm{~kg} \cdot \mathrm{ha}^{-1} \mathrm{~N}$ in cover crop systems with alfalfa, rye, and rye/hairy vetch. Burket et al. (1997) estimated the cover crop combination of clover (Trifolium pratense) alone, or in a mixture with rye and pea, to contribute $150 \mathrm{~kg} \cdot \mathrm{ha}^{-1} \mathrm{~N}$. Our results contrast with results from Creamer et al. (1996) where tomato yields were equal in conventional and cover crop plots. Researchers from California (Scow, 1996; Shennan, 1992 ) reported similar results, however, where cover crop supplementation alone was inadequate for optimal vegetable crop production.

Reduced performance in striptilled plots has been associated with nutrient and water competition between cover crop and vegetable crop. Loy et al. (1987) found that water deficits were higher in strips, leading to lowered marketable pepper yields compared with conventionally tilled plots. Bottenberg et al. (1999) determined a reduced leaf $\mathrm{N}$ content in snap bean plants under strip-tillage, as did Herrero et al. (2001) in striptilled tomato leaves. Cooler soils, delayed maturity, and a later harvest period in a strip-tilled snap beans and corn were observed (Hoyt, 1999; Licht and Al-Kaisi, 2005). Decreased soil temperatures in strips may also lead to increased disease incidence, as reported here and by McKeown et al. (1998). Increasing the strip width may facilitate vegetable crop growth, as Loy et al. (1987) demonstrated improved squash yield after widening the strips from 0.5 to $1 \mathrm{~m}$, but weed management in 1 -m-wide strips in organic systems would require tillage or hand-mulching. In this experiment, an application of straw mulch was required each year to provide adequate weed control in the striptilled systems because of insufficient soil coverage by the cover crop. The straw mulch was needed for supplemental weed control in 2003 despite $\mathrm{a} \approx 153 \%$ increase in hairy vetch/rye biomass from 2002 to 2003 . For complete weed management, additional hand weeding may also be required in straw mulch systems (Law et al., 2006).

Animal-based and cover cropbased fertilization were effective in increasing soil inorganic $\mathrm{N}$ during critical periods in the growing season in all organic treatments. Crop response corresponded with soil fertility results, where complete incorporation of the hairy vetch/rye cover crop increased soil inorganic $\mathrm{N}$ to a greater extent compared with strip-tillage. Carrera et al. (2004) also found that hairy vetch/rye mineralization allowed for a slower release of $\mathrm{N}$ and more efficient absorption by sweet corn. Similar to Wilson et al. (1982), however, improvements in soil organic matter, total $\mathrm{N}$, and decreased bulk density in the strip-tilled plots were not associated with improved yields over tilled plots.

For a leguminous cover crop to supply nutrients equivalent to organic fertilizers, the cover crop stand, overwintering capability, and spring growth must be sufficient. Additionally, mechanical termination of the cover crop must result in evenly distributed mulch of sufficient depth to play a significant role in weed management. Although strip-tillage of vegetables into cover crops can help mitigate soil erosion and aid in weed management, competition between vegetable and cover crop regrowth, inadequate $\mathrm{N}$ contribution, potential cooling of soil, and the requirement for continued strip management throughout the growing season has reduced the adoption of this system on organic farms. To eliminate $\mathrm{N}$ immobilization problems, growers should till cover crops at least 2 weeks before planting vegetables, but this period may prove inadequate if unfavorable weather conditions delay cover crop decomposition. Despite application challenges, cover crops will remain as critical components of the organic farm plan, specifically for their role in sequestering carbon, contributing nutrients, improving soil tilth and microbial populations, interfering with weeds and insect pest cycles, and facilitating the development of a closed-system farm.

\section{Literature cited}

Abdul-Baki, A.A. and J.R. Teasdale. 1997a. Snap bean production in conventional tillage and in no-till hairy vetch mulch. HortScience 32:1191-1193.

Abdul-Baki, A.A. and J.R. Teasdale. 1997b. Sustainable production of freshmarket tomatoes and other summer 
vegetables with organic mulches. 7 June 2007. <http://www.ars.usda.gov/is/np/ SustainableTomato.pdf $>$.

Andow, D.A. 1991. Vegetational diversity and arthropod response. Annu. Rev. Entomol. 36:561-586.

Baker, B.P., C.M. Benbrook, E. Groth, and K.L. Benbrook. 2002. Pesticide residues in conventional, integrated pest management (IPM)-grown and organic foods: Insights from three U.S. data sets. Food Addit. Contam. 19:427-446.

Bottenberg, H., J. Masiunas, and C. Eastman. 1999. Strip tillage reduces yield loss of snapbean planted in rye mulch. HortTechnology 9:235-239.

Burger, M. and L.E. Jackson. 2003. Microbial immobilization of ammonium and nitrate in relation to ammonification and nitrification rates in organic and conventional cropping systems. Soil Biol. Biochem. 35:29-36.

Burket, J.Z., D.D. Hamphill, and R.P. Dick. 1997. Winter cover crops and nitrogen management in sweet corn and broccoli rotations. HortScience 32:664668 .

Carrera, L.M., A.A. Abdul-Baki, and J.R. Teasdale. 2004. Cover crop management and weed suppression in no-tillage sweet corn production. HortScience 39:12621266.

Creamer, N.G. and M.A. Bennett. 1997. Evaluation of cover crop mixtures for use in vegetable production systems. HortScience 32:866-870.

Creamer, N.G., M.A. Bennett, B.R. Stinner, and J. Cardina. 1996. A comparison of four processing tomato production systems differing in cover crop and chemical inputs. J. Amer. Soc. Hort. Sci. 121:559-568.

Dahnke, W.C. and D.A. Whitney. 1988. Measurement of soil salinity, p. 32-34. In: W.C. Dahnke (ed.). Recommended chemical soil test procedures for the North Central region. North Central Region Publ. No. 221 (revised), North Dakota Agr. Expt. Sta., Fargo, ND.

Delate, K. 2002. Using an agroecological approach to farming systems research. HortTechnology 12:345-354.

Delate, K. and J. DeWitt. 2004. Building a farmer-centered land grant university organic agriculture program: A midwestern partnership. Renewable Agr. Food Systems 19:80-91.

Delate, K., H. Friedrich, and V. Lawson. 2003. Organic pepper production using compost and cover crops. Biol. Agr. Hort. 21:131-150.
Dimitri, C. and C. Greene. 2003. Recent growth patterns in the U.S. organic foods market. 8 June 2007. <http://www.ers. usda.gov/publications/aib777/aib777. pdf>.

Eckert, D.J. 1988. Recommended pH and lime requirement tests, p. 6-8. In: W.C. Dahnke (ed.). Recommended chemical soil test procedures for the North Central region. North Central Region Publ. No. 221 (revised), North Dakota Agr. Expt. Sta., Fargo, ND.

Gaskell, M., B. Fouche, S. Koike, T. Lanini, J. Mitchel, and R. Smith. 2000. Organic vegetable production in California: Science and practice. HortTechnology 10:699-713.

Griffin, T., M. Liebman, and J. Jeminson, Jr. 2000. Cover crops for sweet corn production in a short-season environment. Agron. J. 92:144-151.

Gunapala, N. and K.M. Scow. 1998. Dynamics of soil microbial biomass and activity in conventional and organic farming systems. Soil Biol. Biochem. 30:805816.

Herrero, E.V., J.P. Mitchell, W.T. Lanini, S.R. Temple, E.M. Miyao, R.D. Morse, and E. Campiglia. 2001. Use of cover crop mulches in a no-till furrow irrigated processing tomato production system. HortTechnology 11:43-48.

Høgh-Jensen, H. 1998. Systems theory as a scientific approach toward organic farming. Biol. Agr. Hort. 16:37-52.

Hoyt, G.D. 1999. Tillage and cover residue affects on vegetable yields. HortTechnology 9:351-358.

Hoyt, G.D., D.W. Monks, and T.J. Monaco. 1994. Conservation tillage for vegetable production. HortTechnology 4:129-135.

Knudsen, D. and D. Beegle. 1988. Recommended phosphorus tests, p. 12-14. In: W.C. Dahnke (ed.). Recommended chemical soil test procedures for the North Central region. North Central Region Publ. No. 221 (revised), North Dakota Agr. Expt. Sta., Fargo, ND.

Kramer, A.W., T.A. Doane, W.R. Horwath, and C. van Kessel. 2002. Combining fertilizer and organic inputs to synchronize $\mathrm{N}$ supply in alternative cropping systems in California. Agr. Ecosystems Environ. 34:43-50.

Law, D.M., A.B. Rowell, J.C. Snyder, and M.A. Williams. 2006. Weed control efficacy of organic mulches in two organically managed bell pepper production systems. Hort Technology 16:225-232.

Licht, M.A. and M. Al-Kaisi. 2005. Striptillage effect on seedbed soil temperature and other soil physical properties. Soil Tillage Res. 80:233-249.

Loy, S.J.W., L.C. Peirce, G.O. Estes, and O.S. Wells. 1987. Productivity in a strip tillage vegetable production system. HortScience 22:415-417.

MacRae, R.J., S.B. Hill, G.R. Mehuys, and J. Henning. 1993. Farm-scale agronomic and economic conversion from conventional to sustainable agriculture. Adv. Agron. 43:155-198.

Masiunas, J.B., L.A. Weston, and S.C. Weller. 1995. The impact of rye crops on weed populations in a tomato cropping system. Weed Sci. 43:306-311.

McKeown, A.W., R.F. Cerkauskas, J.W. Potter, and L. van Driel. 1998. Long-term evaluation of cover crop and strip-tillage on tomato yield, foliar diseases and nematode populations. Can. J. Plant Sci. 78:341-348.

Morse, R.D. 1999. No-till vegetable production: Its time is now. HortTechnology 9:373-379.

Nelson, W.A., B.A. Kahn, and B.W. Roberts. 1991. Screening cover crops for conservation tillage systems for vegetables following spring plowing. HortScience 6:860-862.

Pimentel, D., T.W. Culliney, I.W. Butler, D.J. Reinemann, and K.B. Beckman. 1989. Low-input sustainable agriculture using ecological management practices. Agr. Ecosystems Environ. 27: 3-24.

Scow, K.M. 1996. Impact of microbial processes on crop use of fertilizers from organic and mineral sources. Proc. 4th Annu. Fert. Res. Educ. Prog. Conf., p. $72-74$.

Shennan, C. 1992. Cover crops, nitrogen cycling, and soil properties in semi-irrigated vegetable production systems. HortScience 27:749-754.

Skarphol, B.J., K.A. Corey, and J.J. Meisinger. 1987. Response of snap beans to tillage and cover crop combinations. J. Amer. Soc. Hort. Sci. 112:936-941.

Snapp, S., S.M. Swinton, R. Labarta, D. Mutch, J.R. Black, R. Leep, J. Nyiraneza, and K. O'Neil. 2005. Evaluating cover crops for benefits, costs, and performance within cropping system niches. Agron. J. 97:322-332.

Thurston, H.D. 1992. Sustainable practices for plant disease management in traditional farming systems. Westview Press, Boulder, CO.

U.S. Department of Agriculture. 2007a. Organic statistics for U.S.: 2005. 8 June 2007. <http://www.ers.usda.gov/data/ Organic/index.htm $>$. 


\section{Research Reports}

U.S. Department of Agriculture. 2007b. National Organic Program. 8 June 2007. <http://www.ams.usda.gov/nop>.

Venterea, R.T. and D.E. Rolston. 2000. Nitric and nitrous oxide emissions following fertilizer application to agricultural soil: Biotic and abiotic mechanisms and kinetics. J. Geophys. Res. 105:1511715127.
Vyn, T.J. and B.A. Raimbault. 1993. Long-term effect of five tillage systems on corn response and soil structure. Agron. J. 85:1074-1079.

Walz, E. 2004. Final results of the fourth national organic farmers' survey: Sustaining organic farms in a changing organic marketplace. Organic Farming Research Foundation, Santa Cruz, CA.
Wilson, G.F., R. Lal, and B.N. Okigbo. 1982. Effects of cover crops on soil structure and on yield of subsequent arable crops grown under strip tillage on an eroded alfisol. Soil Tillage Res. 2:233250 . 